\title{
Significance of Electrocardiographic QTe Interval on Assessment of Left Ventricular Diastolic Dysfunction in Hypertensive Patient: A Simple Screening Tool
}

\author{
Sheila Dhiene Putri*, Harris Hasan, Refli Hasan, A. Afif Siregar, Nizam Akbar, Cut Aryfa Andra \\ Department of Cardiology and Vascular Medicine, Faculty of Medicine, Universitas Sumatera Utara / Haji Adam Malik \\ General Hospital, Medan, North Sumatera, Indonesia \\ ${ }^{*}$ Corresponding Author: \\ Sheila Dhiene Putri, MD, - email: sheiladputri@gmail.com \\ Address: Department of Cardiology and Vascular Medicine, Universitas Sumatera Utara/ Haji Adam Malik General \\ Hospital, Jalan Bunga Lau, Medan, Indonesia
}

Manuscript submitted: August 14, 2018; Revised and accepted: February 12, 2019

\begin{abstract}
Background: Diastolic dysfunction as part of heart failure with preserved ejection fraction (HFpEF) has gain interests, due to the increasing prevalence rate and poor prognosis. Besides the mechanism is not fully understood, there are some difficulties in detecting the presence of diastolic dysfunction. Previous studies have shown correlation between some electrocardiographic parameters and diastolic function. Furthermore, the aim of this study is to assess the diagnostic value of the QTc interval in detecting left ventricular diastolic dysfunction.

Methods: A cross sectional study was conducted on patients with clinical suspicion of heart failure. Electrocardiographic examination was performed to obtain QTc interval (msec) using the Bazett formula. Left ventricular diastolic function was assessed using Tissue Doppler Imaging by echocardiography. Using correlation test and ROC method, the relationships between QTc interval and LV diastolic function were investigated.

Results: Of 82 patients analyzed, there were 62 patients (75.9\%) known to have diastolic dysfunction. The QTc interval was found to be longer in the group with diastolic dysfunction compared to the normal group (442.9 \pm 27 vs. $402.1 \pm 18.2$, $p$ $<0.001)$. There was a strong negative correlation between the QTc interval and diastolic function $(r=-0.619 ; p<0.001)$. Using ROC analysis, the cut off point for QTC interval was 410 ms with $91 \%$ sensitivity, $70 \%$ specificity, and $90 \%$ positive predictive value.
\end{abstract}

Conclusion: The QTC interval is an accurate, simple and highly feasible electrocardiographic parameter as a screening tool to determine the presence of left ventricular diastolic dysfunction.

Keywords: QTc interval; diastolic dysfunction. 


\section{INTISARI}

Latar Belakang: Disfungsi diastolik sebagai bagian dari gagal jantung dengan fraksi ejeksi normal menjadi salah satu penyakit kardiovaskular yang menarik untuk diteliti, sehubungan dengan angka prevalensinya yang semakin meningkat dan prognosis yang kurang baik. Selain mekanismenya belum dipahami sepenuhnya, terdapat beberapa kesulitan dalam mendeteksi adanya disfungsi diastolik. Penelitian sebelumnya menunjukkan adanya korelasi antara beberapa parameter elektrokardiografi dengan fungsi diastolik ventrikel kiri. Tujuan penelitian ini adalah untuk mengetahui nilai diagnostik interval QT terkoreksi dalam menentukan gangguan fungsi diastolik ventrikel kiri.

Metode: Penelitian ini merupakan studi potong lintang yang dilakukan pada pasien yang diduga menderita gagal jantung berdasarkan presentasi klinis. Pemeriksaan elektrokardiografi dilakukan untuk memperoleh nilai interval QT yang dikoreksi menggunakan formula Bazett. Dilakukan penilaian fungsi diastolik ventrikel kiri dengan Tissue Doppler Imaging melalui pemeriksaan ekokardiografi. Analisa statistik dengan uji korelasi, uji diagnostik, serta metode ROC dilakukan untuk mencari nilai titik potong dan menilai hubungan keduanya.

Hasil: Dari total 82 pasien yang dianalisis dalam studi ini, terdapat 62 orang (75,9\%) yang mengalami disfungsi diastolik. Nilai interval QT terkoreksi didapati lebih panjang pada kelompok yang mengalami disfungsi diastolik yaitu 442,9 $\mathrm{ms}$ dibandingkan dengan kelompok fungsi diastolik normal sebesar 402,1 ms $(p<0,001)$. Dijumpai korelasi berbanding terbalik antara nilai interval QT terkoreksi dan fungsi diastolik dengan kekuatan korelasi kuat $(r=-0,618 ; p<0,001)$. Dengan metode ROC, diperoleh nilai titik potong interval QT terkoreksi sebesar $410 \mathrm{~ms}$ dengan sensitivitas $91 \%$, spesifisitas $70 \%$, dan nilai duga positif $90 \%$.

Kesimpulan: Nilai interval QT terkoreksi dari elektrokardiografi dapat menjadi parameter sederhana dan mudah dilakukan sebagai skrining awal untuk mengetahui adanya disfungsi diastolik ventrikel kiri.

\section{INTRODUCTION}

Diastolic dysfunction as part of heart failure with preserved ejection fraction (HFpEF) has gain some interests, due to the increasing prevalence rate and poor prognosis. Besides the mechanism is not fully understood, there are some difficulties in detecting the presence of diastolic dysfunction. Diastolic dysfunction followed by symptoms of heart failure is an entity called HFpEF. It is estimated that around 26 million people worldwide suffer heart failure and will continue to rise with increasing age. ${ }^{1}$ The prevalence of heart failure in the population in developed countries is about $1-2 \%$, and increased to more than $10 \%$ in the population above 70 years of age. The HFpEF patients reported to have increasing risks of all cause death, rehospitalization from heart failure, and a decline in the quality of life that are similar to those with heart failure with reduced ejection fraction (HFrEF). ${ }^{2}$

Considering the poor prognosis of HFpEF, early detection of diastolic dysfunction as a precursor of heart failure is beneficial so that an early management may be given., ${ }^{3,4}$ One common problem in tertiary facilities is the limited access to medical equipment for diagnostic purposes such as echocardiography, which is the main non-invasive modality in determining diastolic function of the heart. In addition, the use of echocardiography to assess complete left ventricular diastolic function requires more than one parameter which is more complicated, takes longer time, and can only be performed by 
echocardiographers or trained clinicians. It demonstrates the need for another simple, inexpensive, and feasible parameter to assess left ventricular diastolic function as a screening tool so that proper management can be performed in patients with impaired left ventricular diastolic function. Previous studies have shown correlation between some electrocardiographic parameters and left ventricular diastolic function. Furthermore, the aim of this study is to assess the diagnostic value of the QTC interval as screening tools in detecting left ventricular diastolic dysfunction.

\section{METHODS}

This study is a cross sectional diagnostic study of patients suspected of having left ventricular diastolic dysfunction at Adam Malik Hospital Medan based on history taking and clinical symptoms. Subjects include hypertensive patients that are treated in our outpatient clinic from March 2018 until July 2018. Patients with rhythm disturbances, electrolyte imbalance, reduced LVEF (EF Simpson <50\%), pericardial disease, severe mitral and aortic valve disease, congenital heart disease, coronary artery disease, obstructive cardiomyopathy disease, antiarrhythmic use that may affects the QT interval, and poor acoustic window were all excluded. Patients who met the inclusion and exclusion criteria were then provided with written informed consent and recruited as subjects.

We documented history of previous disease, history of medication used, weight, height, and risk factors for cardiovascular disease from medical records. All patients underwent electrocardiographic examination using Bionet Cardiotouch 3000 at $25 \mathrm{~mm} / \mathrm{s}$ speed and $10 \mathrm{mV} / \mathrm{mm}$ scale. The result of QT interval and corrected QT interval was measured by cardiology resident using Bazett formula and will be validated by a cardiologist who did not know the course of the patient's history, using a $150 \mathrm{~mm}$ Krisbow caliper dial micrometer (KW0600352) and a magnifying glass. The measurement results are reported in units of msec.

Echocardiography examination was performed using echocardiography GE Vivid S6 with heart probe sector 3.50 MHz. Echocardiography was performed by the resident who was on duty and then validated by a cardiologist

Echocardiography data were documented such as LVEF by biplane method, LVEDD, and IVSD. The left ventricular diastolic function was assessed using Tissue Doppler Imaging including septal e ', lateral e', and $E$ / e ratio on the septum and lateral wall of left ventricle using apical 4-chamber view. For LA volume $\left(\mathrm{mL} / \mathrm{mm}^{2}\right)$ biplane technique was used with apical 4-chamber and apical 2chamber view, at the end of sistole.

Statistical Analysis

We compared the demographic, clinical, electrocardiographic, and echocardiographic parameters between those with normal and reduced septal e' velocity using independent $t$ tests for continuous variables and chi square (or Fisher's exact) tests for categorical variables. The association of corrected QT interval with e' septal velocity was assessed using Spearman correlation test. Next, we used receiver operating characteristic analysis to determine the optimal cut off point of QTC interval. Using the $2 \times 2$ table, we obtained sensitivity, specificity, positive predictive value and negative value of QTc interval in determining LV diastolic function. All statistical analyses were performed using SPSS, version 18.0 and $p$ value $<0,05$ was considered as statistically significant.

\section{RESULTS}

In this study, we enrolled 82 patients who have met the inclusion and exclusion criteria as subjects. 
Table 1. Demographic and clinical characteristics—normal versus reduced tissue Doppler e' velocity.

\begin{tabular}{|c|c|c|c|}
\hline & $\begin{array}{l}\text { e' septal velocity }>7 \mathrm{~cm} / \mathrm{s} \\
(\mathrm{n}=20)\end{array}$ & $\begin{array}{c}\text { e' septal velocity } \leq 7 \\
\mathrm{~cm} / \mathrm{s}(\mathrm{n}=62)\end{array}$ & $\begin{array}{c}\mathrm{p} \\
\text { value }\end{array}$ \\
\hline Age (years), mean $\pm S D$ & $60.3 \pm 8.4$ & $62.6 \pm 10.1$ & 0.227 \\
\hline $\operatorname{Sex}(n, \%)$ & & & 0.122 \\
\hline Male & $11(55.0)$ & $22(35.5)$ & \\
\hline Female & $9(45.0)$ & $40(64.5)$ & \\
\hline Smoker (n, \%) & $5(25.0)$ & $13(20.9)$ & 0.705 \\
\hline Diabetes mellitus (n, \%) & $2(10.0)$ & $19(30.6)$ & 0.066 \\
\hline Dyslipidemia (n, \%) & $11(50.0)$ & $47(75.8)$ & 0.075 \\
\hline Controlled BP (n, \%) & $10(50.0)$ & $30(48.3)$ & 0.942 \\
\hline Duration of Hypertension (n, \%) & & & 0.001 \\
\hline$\geq 5$ years & $10(50.0)$ & $53(85.4)$ & \\
\hline$<5$ years & $10(50.0)$ & $9(14.6)$ & \\
\hline BMl $\left(\mathrm{kg} / \mathrm{m}^{2}\right)$, mean $\pm \mathrm{SD}$ & $25.8 \pm 4.7$ & $25.8 \pm 3.9$ & 0.987 \\
\hline $\mathrm{SBP}(\mathrm{mmHg})$, mean $\pm \mathrm{SD}$ & $138.35 \pm 11.04$ & $139.3 \pm 16.46$ & 0.956 \\
\hline $\mathrm{DBP}(\mathrm{mmHg})$, mean $\pm \mathrm{SD}$ & $79.5 \pm 12.35$ & $81.66 \pm 8.59$ & 0.910 \\
\hline Hear rate ( $x /$ menit), mean $\pm S D$ & $67.8 \pm 7.75$ & $71.6 \pm 11.7$ & 0.103 \\
\hline \multicolumn{4}{|l|}{ Medication $(n, \%)$} \\
\hline Beta blockers & $5(25.0)$ & $20(32.0)$ & 0.540 \\
\hline ACE-inhibitor & $14(70.0)$ & $53(85.5)$ & 0.119 \\
\hline Calcium channel blockers & $15(75.0)$ & 44 (70.9) & 0.727 \\
\hline Diuretic & $1(5.0)$ & $23(37.1)$ & 0.006 \\
\hline
\end{tabular}

Based on the value of $e$ 'septal as a parameter of diastolic function, there were 62 people $(75.2 \%)$ had diastolic dysfunction and 20 people $(24.8 \%)$ had normal diastolic function. The subjects were then divided into two groups, based on their diastolic function. The first group is patients with normal diastolic function ( $\mathrm{e}$ 'septal velocity $\geq 7$ $\mathrm{cm} / \mathrm{s}$ ), while the second group is the subject with diastolic dysfunction (e 'septal velocity $<7 \mathrm{~cm} / \mathrm{s}$ ).

Table 1 shows the baseline characteristics of subjects based on their diastolic function. Variables that are compared include demographic characteristics, risk factors, hemodynamics, and medication used by the subjects. From 82 subjects, 49 women $(59.7 \%)$ were female, and as much as 33 people $(40.3 \%)$ were male. The mean age of subjects was 60.8 years in this study.

Based on risk factors of cardiovascular disease, it was found that more subjects within diastolic dysfunction group had smoking history, dyslipidemia, and diabetes mellitus in 18 (21.9\%), 68 (83.0\%), and 21 $(25.6 \%)$ subjects, respectively. There was a difference in the incidence of a diabetes mellitus, which is higher in the diastolic dysfunction group, compared with the normal diastolic function group (19 $(30.6 \%)$ vs 2 (10.0\%) subjects). Almost half of subjects $(48.7 \%)$ had controlled hypertension with mean systolic blood pressure of $138.4 \mathrm{mmHg}$ and mean diastolic blood pressure was $79.5 \mathrm{mmHg}$, and mean heart rate was $68 \mathrm{bpm}$. The medications used by the patients include beta blockers, ACE inhibitors, calcium channel blockers, and also diuretics. The diuretic was more commonly used in the diastolic dysfunction group, which was 23 patients $(37.1 \%)$, compared with the normal group for only 1 patient $(p=$ 0.006).

Based on echocardiography results, several parameters were found to be statistically different between the 
two groups, including LAVI, e'septal velocity, e'lateral velocity, and E/e ' ratio as listed in Table 2. The mean e' septal and lateral velocities were lower in the group with diastolic dysfunction. LAVI values and $E / e$ ratio were higher in the group with diastolic dysfunction. While ejection fraction, wave velocity $\mathrm{E}$, LVEDD, IVSD, and left atrium diameter did not differ significantly in both groups.

Table 3 shows characteristics of electrocardiography parameters in this study. There were only 9 patients $(10.9 \%)$ of all subjects had abnormal Pwave morphology. Among all subjects, 69 patients (84.1\%) showed normal QRS complex axis. There was a significant difference from the QT interval between two groups. The mean QT interval was $371.3 \mathrm{~ms}$ in normal diastolic function group and $404,8 \mathrm{~ms}$ in diastolic dysfunction group ( $p<0.001)$. The corrected QT interval also not similar, the mean corrected QT interval in the normal group was $404.5 \mathrm{~ms}$, whereas in the group with diastolic dysfunction was $442.4 \mathrm{~ms}(p<0.001)$.

To assess the correlation between corrected QT interval and parameters of left ventricular diastolic function from echocardiography, Spearman correlation test was performed. The result of correlation test showed a strong inverse correlation between QTc value and diastolic function $(r=-0.619, p<0.001)$.

Table 2. Echocardiographic parameters in normal and reduced e' septal velocity groups

\begin{tabular}{lccc}
\hline & $\begin{array}{c}\text { e' septal velocity }>7 \mathrm{~cm} / \mathrm{s} \\
(\mathrm{n}=20)\end{array}$ & $\begin{array}{c}\text { e' septal velocity } \leq 7 \mathrm{~cm} / \mathrm{s} \\
(\mathrm{n}=62)\end{array}$ & p value \\
\hline LVEDD $(\mathrm{mm})$, mean $\pm S D$ & $45.0 \pm 6.1$ & $43.9 \pm 5.1$ & 0.429 \\
IVSD $(\mathrm{mm})$, mean $\pm S D$ & $12.4 \pm 2.3$ & $14.2 \pm 2.5$ & 0.063 \\
EF Simpson (\%), mean $\pm S D$ & $55.8 \pm 6.9$ & $57.3 \pm 6.6$ & 0.517 \\
LA diameter (mm), mean $\pm S D$ & $33.8 \pm 3.9$ & $34.5 \pm 4.6$ & 0.492 \\
LAVI $\left(\mathrm{ml} / \mathrm{m}^{2}\right)$, mean $\pm S D$ & $30.2 \pm 2.1$ & $33.7 \pm 4.6$ & 0.010 \\
E $(\mathrm{m} / \mathrm{s})$, mean $\pm S D$ & $0.74 \pm 0.19$ & $0.69 \pm 0.17$ & 0.259 \\
e' septal $(\mathrm{cm} / \mathrm{s})$ & $9(7-13)$ & $6(4-6)$ & $<0.001$ \\
e' lateral $(\mathrm{cm} / \mathrm{s})$ & $11(7-15)$ & $9(6-13)$ & $<0.001$ \\
E/e' ratio, mean $\pm S D$ & $7.57 \pm 1.9$ & $9.74 \pm 2.4$ & $<0.001$ \\
\hline
\end{tabular}

Table 3. Electrocardiographic parameters in normal and reduced e' septal velocity groups

\begin{tabular}{lccc}
\hline & $\begin{array}{c}\text { e' septal velocity }>7 \mathrm{~cm} / \mathrm{s} \\
(\mathrm{n}=20)\end{array}$ & $\begin{array}{c}\text { e' septal velocity } \leq 7 \mathrm{~cm} / \mathrm{s} \\
(\mathrm{n}=62)\end{array}$ & $\mathrm{p}$ value \\
\hline P wave abnormality $(\mathrm{n}, \%)$ & $3(15)$ & $6(9)$ & 0.508 \\
QRS Axis $(\mathrm{n}, \%)$ & $19(95)$ & $50(80,6)$ & 0.126 \\
$\quad$ Normal & $1(5)$ & $12(19,4)$ & \\
LAD & $371.3 \pm 15.8$ & $404.8 \pm 33.2$ & 0.001 \\
QT interval (ms), mean $\pm S D$ & $404.5 \pm 19.8$ & $442.4 \pm 28.3$ & $<0.001$ \\
QTc interval (ms), mean $\pm S D$ & &
\end{tabular}


The correlation test result can be interpreted as follows, the higher the corrected QT interval value of the electrocardiography the lower the e'septal velocity from the echocardiography, while the reduced e 'septal velocity reflects abnormal diastolic function. On the contrary, the lower the value of the corrected QT interval will be the higher the e'septal value of echocardiography. The correlation between these two variables is also shown in the form of a scatter plot graph (Figure 1).

The diagnostic value of QTC interval to determine left ventricular diastolic dysfunction was assessed by Receiver Operating Characteristic
(ROC) and Area Under Curve (AUC) methods. The obtained AUC value was $86.9 \%$ with $77.9 \%-95.9 \%$ confidence interval $(95 \% \mathrm{Cl}, \mathrm{p}<0.001)$, which is statistically strong as shown in Figure 2.

There were 57 patients (91\%) who had a QTc interval $\geq 410 \mathrm{~ms}$ and were shown to have diastolic dysfunction by echocardiography, whereas 14 patients $(70 \%)$ had a QTc interval $<410 \mathrm{~ms}$ with normal diastolic function. The diagnostic value of the QTc interval $\geq 410 \mathrm{~ms}$ in determining diastolic dysfunction had a $91 \%$ sensitivity, $\quad 70 \%$ specificity, $90 \%$ positive predictive value, and $74 \%$ negative predictive value $(p<0.001)$.

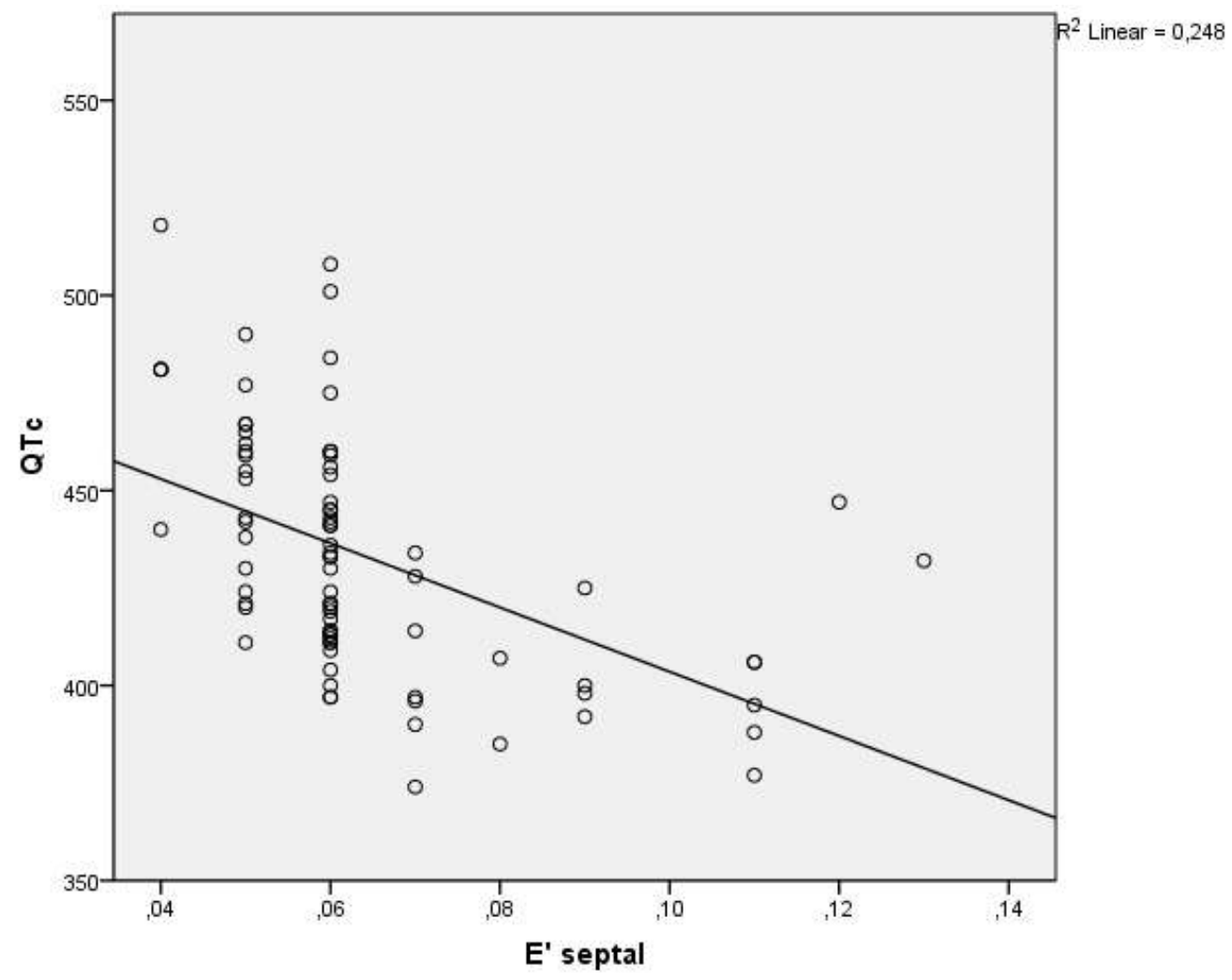

Figure 1. Scatter plot graph shows correlation between QTc interval (msec) and Tissue Doppler e' septal velocity $(\mathrm{cm} / \mathrm{s})$. 


\section{DISCUSSION}

In our study, majority of subjects were female (49 subjects or $59.7 \%$ ), although not significantly different between both groups. From a study that was specifically conducted in HFpEF population, it was found that female gender was more likely to have HFpEF at a 2: 1 ratio $^{6}$. This result thought to be affected by the poor adaptation of remodelling process in hypertensive women, making it easier to develop left ventricle hypertrophy and increasing LV stiffness ${ }^{7}$.

Other risk factors for cardiovascular disease such as type 2 diabetes mellitus and dyslipidemia are also more common in patients with diastolic dysfunction. Of the group found 19 subjects suffered from type 2 diabetes mellitus and 47 people suffered from dyslipidemia. This is supported by prior studies, where the type 2 diabetes mellitus, hypertension, hyperlipidemia, and CHD were more common in groups with reduced $e$ 'septal velocity.

The mean age of this study subjects was 60 years. These results are also not much different from previous studies with mean age between 57-60 years. ${ }^{8,9}$ In population above 50 years of age, the likelihood of developing to diastolic dysfunction is three fold higher. The aging process is thought to act as a substrate in the pathophysiology of HFpEF although it is not fully understood. ${ }^{4}$ The aging process of diastolic dysfunction is proved by the presence of fibrosis in the histopathological analysis. ${ }^{10}$

In this study there were significant differences of the duration of hypertension between the two groups. The results showed that there were 53 patients $(85.4 \%)$ suffering from hypertension for more than 5 years experienced diastolic dysfunction, while only 9 patients (14.6\%) suffered from hypertension less than 5 years $(p=$ 0.001 ). This results supported with prior studies on diastolic dysfunction. It was shown that deterioration in left ventricular diastolic function in $15.4 \%$ of patients who previously had grade I diastolic dysfunction to grade II dysfunction happened within 4 years ${ }^{4}$. From a study conducted on 388 patients to know the natural history of diastolic dysfunction, found a worsening of symptoms in $11.8 \%$ of patients with diastolic dysfunction after 3 years. ${ }^{9}$ These results support the fact that a longer duration of hypertension may be a predictor of heart failure event.

Among the diastolic dysfunction population, one of the most common and associated comorbidity is hypertension. In hypertension, there is a change in the left atrial dimension accompanied by the thickening of the left ventricular septal and posterior wall which later becomes left ventricular hypertrophy with concentric or remodeling pattern. ${ }^{11}$ IVSD values in this study were higher in the diastolic dysfunction group with mean of 14.2 $\mathrm{mm}$.

The QTC interval has a diagnostic value in this study. There was a strong correlation between the QTc interval and e' septal velocity ( $r=-$ 0.619 ; $p<0.001$ ).

This result is consistent with prior studies conducted by Wilcox et al. In the study, there was a strong correlation between the two variables with Spearman's rho value of -0.54 ( $p$ $<0.001) .{ }^{8}$ Another study by Tamer et al also showed some ECG parameters can be used to detect left ventricular diastolic dysfunction. One of the parameters analyzed is the QTc interval value that has enough correlation with the ratio $E / e^{\prime}(r=0.46 ; p<0.001) .{ }^{12}$ 


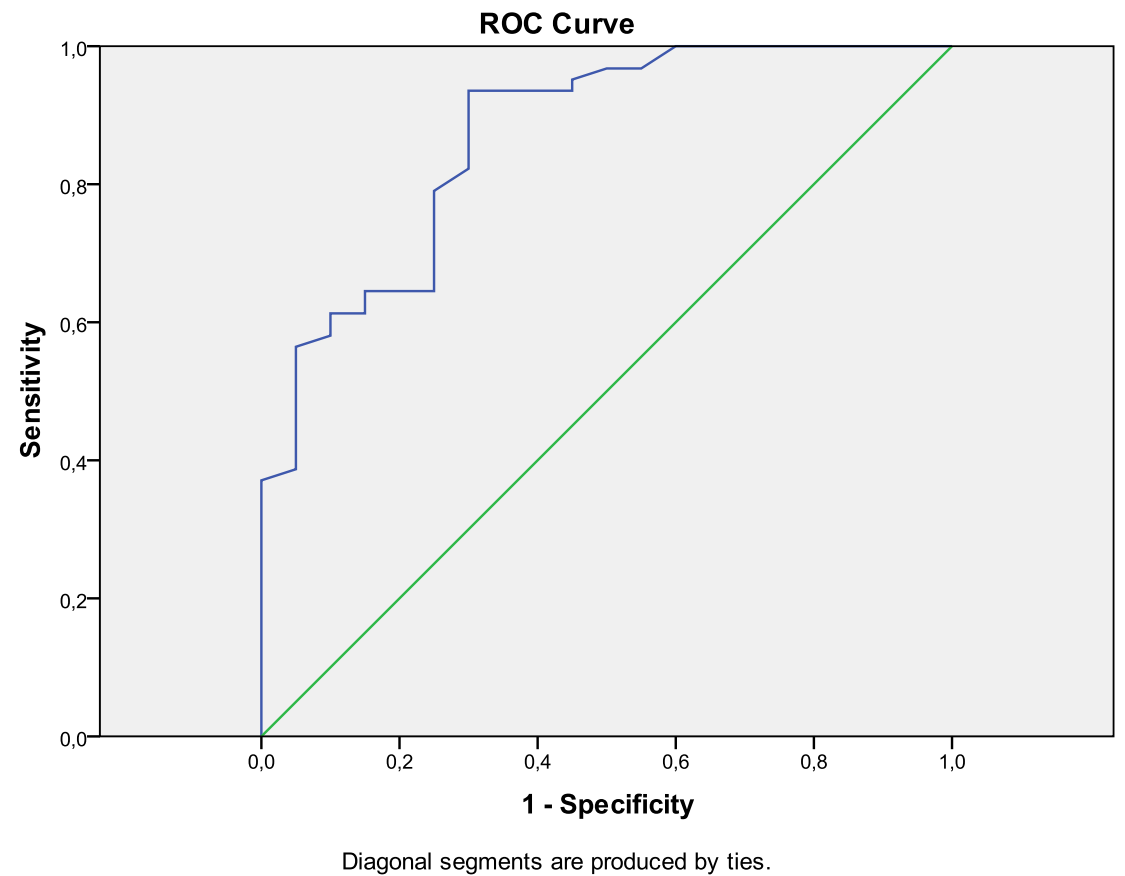

Figure 2. ROC curve of QTc interval to assess left ventricular diastolic dysfunction.

The results of this study indicate the presence of electrocardiographic parameters associated with diastolic dysfunction assessed from echocardiography. In patients with diastolic dysfunction, ventricular repolarization from the epicardial to the endocardial occurs heterogeneously so that the duration of the action potential is prolonged. The longer duration of action potential is reflected in the electrocardiographic parameters, one of which is the QT interval. ${ }^{11,13}$

The cut-off point of QTc interval to determine the presence of left ventricular diastolic dysfunction in this study was $410 \mathrm{~ms}$. When compared to previous studies, there is a difference in the cut off point of QTc interval. A study conducted in 140 patients suspected of having coronary heart disease, showed the result that the QTc interval value point of $\geq 395 \mathrm{~ms}$ had a diagnostic value for left ventricular diastolic dysfunction. ${ }^{12}$ Another study of QTC interval and diastolic function showed a cutoff value of $\geq 435 \mathrm{~ms}^{8}$
The differences of cut off point between these study itself may be due to population differences, whereas in previous studies patients with coronary heart disease were included in the analysis. In addition, electrocardiographic measurements may also confound the results. The QTC interval in a previous study was calculated from ECG obtained during exercise stress test. ${ }^{12}$ To date, there are many formulas that can be used to calculate corrected QT intervals, such as the Bazett, Hodges, Framingham, Fredericia, and Rautaharju algorithms. Each of these formulas has different cut off point. ${ }^{14}$

Clinical guideline issued by the AHA on electrocardiographic interpretation suggests that the cutoff point of the QT interval should be adjusted to the formula used for the correction and purpose of using the QT interval itself. In general, the corrected QT interval is said to be prolonged if more than 450 $\mathrm{ms}$ and is said to be shortened if less than $390 \mathrm{~ms}^{15}$ Therefore, in this study we found a cut off point of $\geq 410 \mathrm{~ms}$ 
which can be used to determine the presence of left ventricular diastolic dysfunction in HFpEF patient populations without CHD-associated disease and using Bazett and Hodges as correction formula.

\section{CONCLUSION}

This study suggests that QTC interval might be used as a simple, feasible, and accurate screening tool for diastolic dysfunction, so that further examination and early management can be performed to improve clinical outcome of patients with diastolic dysfunction or HFpEF.

\section{REFERENCES}

1. Bui A.L., Horwich T.B., Fonarow G.C. 2011. Epidemiology and risk profile of heart failure. Nat Rev Cardiol, 8:30-41.

2. Lanier G.M.,Vaishnava P., Kosmas C.E., Wagman G., Hiensch R., Vittorio T.J., et al. 2012. An update on diastolic dysfunction. Cardiol Rev, 20:230-236.

3. Ponikowski P., Voors A.A., Anker S.D., Bueno H., Cleland J.G.F., Coats A.J.S., et al. 2016. 2016 ESC Guidelines for the diagnosis and treatment of acute and chronic heart failure. Eur Heart J, 37:2129-2200.

4. Kane G.C., Karon B.L., Mahoney D.W., Redfield M.M., Roger V.L., Burnett J.C., et al. 2011. Progression of Left Ventricular Diastolic Dysfunction and Risk of Heart Failure. JAMA, 306:856-863.

5. Schillaci G., Pasqualini L., Verdecchia P., Vaudo G., Marchesi S., Porcellati C., et al. 2002. Prognostic significance of left ventricular diastolic dysfunction in essential hypertension. J Am Coll Cardiol, 39:2005-2011.
6. Duca F., Zotter-Tufaro C., Kammerlander A.A., Aschauer S., Binder C., Mascherbauer J., et al. 2018. Gender-related differences in heart failure with preserved ejection fraction. Nature, 8:1080.

7. Scantlebury D.C., Borlaug B.A. 2011. Why are women more likely than men to develop heart failure with preserved ejection fraction?. Curr Opin Cardiol, 26:562-568.

8. Wilcox J.E., Rosenberg J., Vallakati A., Gheorghiade M., Shah S.J. 2011. Usefulness of electrocardiographic QT interval to predict left ventricular diastolic dysfunction. Am J Cardiol, 08:1760-1766.

9. Vogel M.W., Slusser J.P., Hodge D.O., Chen H.H. 2012.

The natural history of preclinical diastolic dysfunction: a population-based study. Circ Heart Fail, 5:144-151.

10. Mottram P.M., Marwick T.H. 2005. Assessment of diastolic function: what the general cardiologist needs to know. Heart, 91:681-695.

11. Namdar M., Biaggi P., Stähli B., Butler B., Casado-Array R., Ricciardi D., et al. 2013. A novel electrocardiographic index for the diagnosis of diastolic dysfunction. PLOS ONE, 8: e79152.

12. Tamer T., Sayed K., Saad M., Samir M. 2016. How accurate can electrocardiogram predict left ventricular diastolic dysfunction? The Egyptian Heart Journal, 68:117-123.

13. Sauer A., Wilcox J.E., Andrei A., Passman R., Goldberger J.J., Shah S.J. 2012. Association of the ECG T-peak to T-end interval with echocardiographic markers of diastolic dysfunction. Circ Arrhythm Electrophysiol, 5:537-543. 
14. Vanderberk B., Vandael E., Robyns T., Vanderberghe J., Garweg C., Foulon V., et al. 2016. Which QT correction formulae to use for QT monitoring? J Am Heart Assoc, 5:e003264.

15. Rautaharju P.M., Surawicz B.,
Gettes L.S. 2009.

Recommendations for the standardization and interpretation of the electrocardiogram. Part IV: The ST segmen, $T$ and $U$ waves. J Am Coll Cardiol, 53:982. 